\title{
Determinants of Equity Investments by Long-Term Institutional Investors: Evidence from Brazil
}

\author{
Andre Carvalhal da Silva*, Christiane Tsai and Margarida Gutierrez \\ Coppead Graduate Business School at Federal University of Rio de Janeiro, Brazil
}

\begin{abstract}
This paper analyses the determinant factors of equity investments made by insurance companies, and pension funds. Brazil offers an interesting case study, because these institutional investors have a huge potential in increasing their equity investments in the future, because their investments in stocks nowadays are far below the limits imposed by regulators. Therefore, understanding what kind of companies these institutions would be willing to invest is important to help them on their efforts to attract these investors. Two kinds of analyses are performed. First, we use a logit model in order to estimate the probability for a given company to be in these investors' portfolios. Then we run regressions to analyze the determinants of the size of stock ownership of these investors in a given company. Our results indicate that these investors tend to invest in large, liquid, leveraged companies with good corporate governance practices.
\end{abstract}

Keywords: Equity investments, institutional investors, Brazil.

\section{INTRODUCTION}

Insurance companies and pension funds receive contributions from participants and invest the proceeds. The benefits are paid when an accident occurs or when the participant retires. The success and financial sustainability of these institutions depends heavily on their investment strategy.

In Brazil, these institutions are regulated by the Superintendence of Private Insurance (SUSEP) in the case of insurance companies, and by the Superintendence of Pension Funds (PREVIC) in the case of pension funds. Furthermore, they must follow prudential rules in order to secure the reserves of the participants in the future. There are rules establishing the types of assets allowed for investment by these institutions and the maximum amount that can be invested in each asset class.

Currently most of their investments are represented by fixed income assets, whose return and risk have been very attractive in Brazil. This framework, however, is changing and tends to change even more. The economic policy of the Brazilian government has pursued a path of gradual decline of real interest rate, keeping inflation under control. Moreover, the macroeconomic environment has favored the raising of funds in capital markets by enterprises, and this market is becoming increasingly developed. In this context, the need to diversify risks and maximize returns can encourage institutional investors to invest more in equity.

In this study, we treat pension funds separately from insurance companies, because there are some differences in the nature of these two groups in Brazil. First, pension funds invest more in the long term when compared to insurance companies. There are also differences regarding the regulation of investments. Pension funds, for example, have their

*Address correspondence to this author at the Coppead Graduate Business School at Federal University of Rio de Janeiro, Brazil;

Tel: (5521) 2172-8246; E-mails: andrec@coppead.ufrj.br actuarial liabilities geared more for the long term when compared with insurance companies. Further, pension funds have the obligation to formulate a policy of annual investment and to have a supervisory board, which has to manifest itself on the adherence of the application of resources to current standards and investment policy.

The limits for investing in equity for insurance companies and pension funds are also different. Pension funds can invest in equities up to $70 \%$ of the portfolio, whereas this limit is lower for insurance companies (49\%). Another important difference refers to the history of these two types of institutions. Pension funds have played a significant role in the Brazilian stock market through acquisitions made according to the National Privatization Program (PND), established in 1991, which led to the privatization of government stakes.

The aim of this study is to examine the equity investments of insurance companies and pension funds in order to determine what kind of companies these institutions give preference when making their equity investments. Our goal is to determine whether certain variables (firm size, beta, leverage, dividend yield, volatility, liquidity and corporate governance) explain the equity ownership of these institutions.

We conduct two types of analysis. First, we run a logit model to estimate the probability that a company be in the portfolios of these investors. Then, we run regressions to examine the effect of several variables on the size of the equity shareholding of these investors in a given company.

Our results indicate that insurance companies tend to invest in large, liquid, leveraged companies with good corporate governance practices. Pension funds give preference to large companies with good corporate governance practices. Furthermore, the size of the equity ownership of these investors in a given company is not influenced by firm-specific characteristics. 


\section{REVIEW OF LITERATURE}

In the international literature we find many studies analyzing investments of institutional investors and pension funds. However, only a few studies address the characteristics of insurance companies' investments separately. Badrinath and Wahala [1] examine the U.S. pension funds by comparing them with other institutional investors such as insurance companies, banks and mutual funds. They find that pension funds do not usually trade based on historical prices when compared with other institutional investors. Jones, Lee and Weis [2] report that the pension funds trade based on historical prices when they are buying stocks and when the investment is related to small companies with a performance record of high returns.

Cummings and Westerfield [3] show that the Employee Retirement Income Securitiy Act (ERISA) of 1974 affected the investment policies of pension funds, concluding that: a) the concentration of portfolios has declined since ERISA; $b$ ) the portfolios are less diversified than the market portfolio, and c) equity investments were concentrated in stocks of high market value.

Blake, Lehmann and Timmermann [4] claim that laws affects investments, resulting in different behavior patterns with regard to investments of pension funds. Voronkova and Bohl [5] analyze the pension funds of Poland and show that institutional investors exhibit a group behavior and follow a strategy based on historical prices compared with developed countries. These results are attributed to stringent regulation and high market concentration.

With regard to institutional investors, there are numerous studies that examine the characteristics of equity investments. Hessel and Norman [6] investigate why some shares are preferred by these investors and others are not. Using discriminant analysis, they show that institutional investors prefer investing in firms with high return on equity, return on assets and dividend payments.

Cready [7] examines the determinants of demand for stocks by institutional investors. The results indicate that the demand for riskier stocks of larger companies with low dividend yield is positively related to the size of the investor. Moreover, this study finds that, in comparison with individual investors, institutional investors have a preference for stocks of large firms, firms present in the S \& P 500 and firms with low dividend yield.

Eakins, Stansell and Wertheim [8] examine the role of firm-specific factors (beta, and various financial indicators) in determining the investment of institutional investors. They find that financial institutions seem to avoid investments with extreme (both low and high) financial indicators, such as beta, return on assets and leverage.

Eakins, Stansell and Buck [9] studied a series of financial indicators commonly used by financial analysts in investment decisions, such as beta, firm size and liquidity, and the results suggest a non-linear relation with equity ownership in a particular firm. Like Eakins, Stansell and Wertheim [8], they find that institutional investors tend to avoid extreme values of these indicators.

Eakins, Stansell and Below [10] examine the determinants of equity investment by institutional investors and find that they seek high beta stocks and avoid stocks with high nonsystematic risk. The result indicates that investors value the stock based on the attributes of individual firms, appear to be strongly influenced by measures of ex post market return and have an aversion to variance, skewness and kurtosis in returns.

Badrinath, Gay and Kale [11] show that the traditional models of asset pricing, which usually consider only the riskreturn characteristics, may be omitting an important variable: the potential safety of a given asset. The authors investigate the patterns in the aggregate ownership of institutional investors, focusing on the characteristics of firms that they include in their portfolios. The study concludes that the company's security attributes are important for institutional administrators and, in addition to the generally accepted criteria of past performance, firm size and liquidity, the aggregate ownership of institutional investors in a particular firm is highly sensitive to the potential for external validation.

The authors argue that this is due to the fact that the managers of these portfolios are monitored and evaluated under the "prudent man rule". So, besides the usual security inherent in investment decisions, the managers of these portfolios are concerned about whether their decisions will be considered reasonable and prudent if they need to defend their decisions in court.

Badrinath, Kale, and Ryan [11] analyze the various investment decisions of institutional investors. The results indicate that beta, firm size, volatility, liquidity, time of listing on the stock market and past performance are not statistically significant in explaining the equity ownership of insurance companies. However, while the security features of a firm do not explain the size of equity shareholding of insurance companies, they have a good explanatory power when considering an investment of more fundamental choice: to invest or not in a firm. Firms in which insurance companies invest seem more cautious than the firms that they do not invest.

\section{METHODOLOGY}

\subsection{Logit and Linear Regressions}

Our analysis is performed in two steps. First, we run logit models to estimate the probability that a company be in the portfolio of insurance companies or pension funds. Then, we run linear regressions to examine the effects of some variables on the size of the equity stake in a given company held by insurance companies or pension funds. Therefore, the difference between the two tests is that: a) first we are interested in determining which variables explain the presence of a certain company in the portfolio of insurance companies or pension funds; b) then our goal is to examine whether these variables explain the size of the shareholding in the company held by insurance or pension funds.

The database of the first analysis includes all companies listed on the Sao Paulo stock exchange (BMF\&Bovespa) with available data (ownership structure, beta, liquidity, leverage, dividend yield, volatility and level of corporate governance). In the second analysis, we used a smaller database containing only firms in which insurance companies and pension funds have an equity stake. The following models were estimated for both insurance companies and pension funds in 2006: 


$$
\log \frac{\text { Part }_{i}}{1-\text { Part }_{i}}=\alpha_{0}+\alpha_{1} \text { Beta }_{\mathrm{i}}+\alpha_{2} \text { Liq }_{\mathrm{i}}+\alpha_{3} \operatorname{Siz}_{\mathrm{i}}+\alpha_{4} \mathrm{Lev}_{\mathrm{i}}+
$$$$
\alpha_{5} \operatorname{Div}_{\mathrm{i}}+\alpha_{6} \mathrm{Vol}_{\mathrm{i}}+\alpha_{7} \mathrm{GC}_{\mathrm{i}}+\omega_{\mathrm{i}}
$$

SizPart $_{i}=\beta_{0}+\beta_{1}$ Beta $_{i}+\beta_{2} \operatorname{Liq}_{i}+\beta_{3} \operatorname{Siz}_{i}+\beta_{4} \operatorname{Lev}_{i}+\beta_{5} \operatorname{Div}_{i}+$ $\beta_{6} \mathrm{Vol}_{\mathrm{i}}+\beta_{7} \mathrm{GC}_{\mathrm{i}}+\xi_{\mathrm{i}}$

where Part $_{i}$ is a dummy variable that takes the value 1 when firm $i$ is present in the equity portfolio of insurance companies or pension funds, SizPart $t_{i}$ is the size of the equity shareholding of the insurance companies/pension funds in firm $i$ (number of shares of firm $i$ belonging to these institutions divided by total shares of firm $i$ ), Beta $i$ is the beta of firm $i$ (calculated through the relation of the monthly returns of firm $i$ and the Sao Paulo stock exchange index - Ibovespa in the last 36 months), $\mathrm{Liq}_{i}$ is the liquidity of firm $i$ (annual volume traded of firm $i$ on the Sao Paulo stock exchange in 2006 divided by market value of firm $i$ ), Siz $z_{i}$ is the size of firm $i$ (logarithm of total assets), $L e v_{i}$ is the leverage ratio of firm $i$ (financial debt divided by total assets), $D i v_{i}$ is the dividend yield of firm $i$ (annual dividends divided my market price), $\mathrm{Vol}_{i}$ is the volatility of firm $i$ (standard deviation of daily returns of firm $i$ in 2006), $G C_{i}$ is a dummy variable that takes the value 1 when firm $i$ belongs to the special corporate governance levels of BM\&FBovespa and 0 otherwise.

\subsection{Potential Determinants of Equity Ownership of In- surance and Pension Funds}

Although we treat pension funds separately from insurance companies, we do not believe that there is difference between the determinants of equity ownership of these institutions in Brazil. Despite their different nature and regulation, both investors prefer to invest in fixed-income assets rather than equities, because of the high interest rate environment in Brazil. Although the limits for investing in equity by insurance companies and pension funds are high $(49 \%$ and $70 \%$ of the portfolio, respectively), these institutions invest much lower than this limit in Brazil.

Therefore, we expect that the evidence found in the international literature as determinants of the equity ownership of institutional investors (firm size, beta, leverage, dividend yield, volatility, liquidity and corporate governance) to apply for both pension funds and insurance companies in Brazil.

\subsubsection{Beta}

It is unclear whether insurance companies and pension funds prefer firms with high or low betas. Low betas present less risk, but high betas are associated with higher expected returns. Many studies report that institutional investors prefer high betas. O'Brien and Bhushan [13] find that the beta is positively related to the ownership of institutional investors in a multi-year study using more than 500 companies. Cready [7] and Badrinath, Gay and Kale [11] report significant coefficients when the ownership is related to the beta. They conclude that institutional investors prefer companies with higher risk, which goes against the idea that institutional investors are motivated to be cautious.

Badrinath, Gay and Kale [11] argue that if a manager is compensated with a remuneration scheme symmetrical about a market index, he gets a bonus if the portfolio outperforms the market and has a loss if the portfolio underperforms the market. If there are no legal costs, the manager will be indif- ferent to the beta of the portfolio because the expected value of the incentive is zero. However, the existence of legal costs, the total cost in case of underperformance will be relatively greater than the benefit in case of superior performance and the manager will therefore have an incentive to hold stocks with lower betas.

On the one hand, holding a stock with high beta increases the expected return, which suggests a positive relationship between beta and equity participation. On the other hand, holding a stock with high beta can have a negative connotation, indicating that the holder is at greater risk. Therefore, the hypothesis about the relationship between shareholdings of institutional investors and beta is unclear, and the empirical tests of this paper should help to shed light which effect is stronger.

\subsubsection{Size and Liquidity}

Large firms are usually considered less risky than small ones, because they tend to be older, have greater flow of information, and have better access to capital markets. If an investor is primarily concerned with return, he should avoid large firms, and there is substantial evidence that small firms provide better returns. On the other hand, if an investor is interested in a conservative strategy, he might prefer to invest in bigger firms.

According to Badrinath, Gay and Kale [11], institutional investors restrict their investments to shares of firms with high market value, while individual investors prefer the stocks of companies with low market value. The resultant hypothesis therefore is that ownership is positively related to firm size.

Similarly, the shareholding must be an increasing function of the liquidity of a stock for several reasons. First, high liquidity is generally associated with large firms. Second, to minimize the cost of investment demand, institutions avoid over-diversification. Then, as the amount that institutions invest is substantial, large transactions made by them can exert significant pressures on the price if liquidity is low. To avoid this pressure on the price institutional investors prefer stocks with high liquidity.

\subsubsection{Leverage}

Leverage is another measure of risk of a company. The increase in liabilities may result in an increased risk and expected return. This measure is positively related to total risk and market risk of a firm. Because of this positive relationship with overall risk, leverage should be negatively related to ownership of institutions. However, due to possible positive relationship between beta and the equity stake, and given that leverage and beta are positively related, a positive association between leverage and ownership interest may also exist.

\subsubsection{Dividend}

The relationship between dividends, firm value, and risk has been extensively studied. Jensen and Meckling [14] found that dividends may be perceived by investors as a tool for minimizing agency costs. Additionally, these authors suggest that the dividend payment may require a greater flow of information and market discipline. Black [15] concludes 
that investing in a company not paying a dividend can be considered reckless.

Lintner [16] and Gordon [17] argue that the market price of the shares is directly proportional to the increase in dividend distribution and is inversely proportional to the rate of return required by shareholders. When dividends are high, investors demand a lower return rate, because capital gains are more uncertain than dividends. From this perspective, risk-averse investors prefer dividends to capital gains currents.

\subsubsection{Volatility}

The volatility has been used by Badrinath, Kale, and Ryan [12] and Badrinath, Gay and Kale [11], because, despite the modern theory suggests that only market risk is relevant to the investment decision, institutional investors should consider the overall risk of each firm. Therefore, both the total risk and the market risk must be explicitly considered as determinants of the level of equity participation. The authors argue that the relationship between ownership and total risk (measured by standard deviation of return) is negative because of the propensity of managers to avoid large individual losses.

\subsubsection{Corporate Governance}

Badrinath, Kale, and Ryan [12] and Badrinath, Gay and Kale [11] use a dummy variable (a share ranking) that takes the value 1 if the stock is ranked above $\mathrm{C}$ by Standard \& Poor's and 0 otherwise. According to the authors, the ranking works as an external validation, and a robust test would assess the empirical relationship between ownership and external validation.

In this context, if insurance companies and pension funds are concerned with what others see on their investments, it is critical that firms in which they invest are valued in some way. Belonging to the levels of governance of BM\&FBovespa means that the company adhered to a set of good governance practices, more stringent than those present in the Brazilian legislation. These rules expand the rights of shareholders and improve the quality of information provided by companies and can serve as an external validation.

This classification gives those who are investing a greater credibility for the company and can also function as an indicator to others that investment is more secure and reliable. Carvalho [18] found that the migration of companies already listed on the levels of governance has a positive impact on the valuation of shares and increase liquidity.

\section{DATA}

\subsection{Sources}

Data on equity investment of insurance companies and pension funds come from Superintendence of Private Insurance (SUSEP), Brazilian Clearing and Depository (CBLC), and Brazilian Securities and Exchange Commission (CVM). In the case of insurance companies we analyze only direct investments in stocks, because the indirect ownership structure was not available. For equity investments of pension funds, we consider both direct and indirect ownership.

The information of total number of shares, company size, beta, leverage, dividend yield, liquidity and volatility were obtained from Economatica, and information on corporate governance was obtained from BM\&FBovespa.

\subsection{Summary of Data}

We calculated the equity shareholdings of insurance companies and pension funds for each stock traded on BM\&FBovespa. We calculated the total equity stake, combining common and preferred shares. We use the most liquid share to calculate beta, liquidity and dividend yield.

In 2006, these investors were managing a total $\mathrm{R} \$ 424$ billion in assets or $18 \%$ of GDP in Brazil. The percentage of investment in equities was $33.32 \%$ for pension funds, and $2.73 \%$ for insurance companies, much lower than the legal limits (70\% and 49\%, respectively). Therefore, we can see there is still room for an increase in equity investment by pension funds and a great potential for increase in equity investment by insurance companies.

It is important to highlight the macroeconomic situation of Brazil in 2006. The country had one of the largest economy in the world, with a GDP of USD 1.09 trillion, but income inequality and job creation were still a concern (GDP per capita of USD 5,900 and unemployment rate of $8.4 \%$ ). Inflation has been controlled through an inflation target regime since 1998 , reaching $3.14 \%$ per annum in 2006 . In order to control inflation, Brazil had one of the highest interest rate in the world (13\% per annum). In terms of external situation, Brazil had international reserves of USD 85.8 billion, trade balance of USD 46.5 billion, and net external debt of $6.9 \%$ of GDP.

Table 1 presents the mean (median) values of the potential determinants of equity investments of insurance companies and pension funds. In 2006, insurance companies had equity investments in 103 companies. However, only 73 companies had complete data to perform the study. The pension fund had equity stakes in 81 companies, of which only 54 had complete data for all variables.

For insurance companies, we see that, except for leverage and dividend yield, the differences in mean and median are significant. Companies that are in the portfolios of insurance companies are more liquid, larger and have greater market risk and lower overall risk. Moreover, companies invested by insurance companies have better corporate governance practices $(40 \%$ of them are on the governance levels of BM\&FBovespa compared with $10 \%$ of companies out of their portfolio).

For pension funds, the differences are significant only for size, total risk and governance. Companies invested by pension funds are larger, have lower overall risk and provide better corporate governance practices $(35 \%$ of them are on the governance levels of BM\&FBovespa compared with $16 \%$ of companies out of their portfolio).

\section{RESULTS}

Table 2 presents the results of the logit model to estimate the probability that a company be in the portfolio of insurance companies or pension funds. For insurance companies, liquidity and size are significantly positive, indicating that insurance companies tend to invest in large and liquid companies. Leverage also has a positive coefficient, which reject 
Table 1. Potential Determinants of Equity Investments by Insurance Companies and Pension Funds in Brazil

Mean (Median) values of Equity Investment and its Potential Determinants in the Portfolios of Insurance Companies and Pension Funds in December 2006. Median Values are Shown in Parentheses. The Definition of Each Variable can be Found in Section 3. ***, ** $\mathrm{e} *$ Denote Statistical Significance of the Test of Mean (Median) at 1\%, 5\% and 10\%, Respectively

\begin{tabular}{|c|c|c|c|c|c|c|c|c|}
\hline Companies & $\begin{array}{c}\text { SizPart } \\
(\%)\end{array}$ & $\begin{array}{l}\text { Liq } \\
(\%)\end{array}$ & Beta & $\begin{array}{l}\text { Lev } \\
(\%)\end{array}$ & $\begin{array}{l}\text { Div } \\
(\%)\end{array}$ & $\begin{array}{l}\text { Vol } \\
(\%)\end{array}$ & Siz & GC \\
\hline $\begin{array}{l}\text { Owned by insurance companies } \\
\text { (73) }\end{array}$ & $\begin{array}{c}0.56 \\
(0.42)\end{array}$ & $\begin{array}{c}81.87 \\
(77.23)\end{array}$ & $\begin{array}{c}0.72 \\
(0.69)\end{array}$ & $\begin{array}{c}90.48 \\
(82.54)\end{array}$ & $\begin{array}{c}3.80 \\
(3.20)\end{array}$ & $\begin{array}{c}36.23 \\
(32.21)\end{array}$ & $\begin{array}{c}21.96 \\
(21.20)\end{array}$ & $\begin{array}{c}0.40 \\
(0.00)\end{array}$ \\
\hline $\begin{array}{l}\text { Not owned by insurance compa- } \\
\text { nies }(120)\end{array}$ & $\begin{array}{c}0.00 \\
(0.00)\end{array}$ & $\begin{array}{c}4.76 \\
(4.32)\end{array}$ & $\begin{array}{c}0.41 \\
(0.38)\end{array}$ & $\begin{array}{c}65.10 \\
(63.67)\end{array}$ & $\begin{array}{c}4.05 \\
(3.90)\end{array}$ & $\begin{array}{c}45.23 \\
(42.32)\end{array}$ & $\begin{array}{c}20.16 \\
(19.80)\end{array}$ & $\begin{array}{c}0.10 \\
(0.00)\end{array}$ \\
\hline $\begin{array}{l}\text { Owned by pension } \\
\text { funds ( } 54)\end{array}$ & $\begin{array}{c}14.10 \\
(13.85)\end{array}$ & $\begin{array}{c}36.28 \\
(33.56)\end{array}$ & $\begin{array}{c}0.57 \\
(0.52)\end{array}$ & $\begin{array}{c}30.01 \\
(29.34)\end{array}$ & $\begin{array}{c}4.16 \\
(3.92)\end{array}$ & $\begin{array}{c}37.42 \\
(34.65)\end{array}$ & $\begin{array}{c}21.53 \\
(20.43)\end{array}$ & $\begin{array}{c}0.35 \\
(0.00)\end{array}$ \\
\hline $\begin{array}{l}\text { Not owned by pension } \\
\text { funds (139) }\end{array}$ & $\begin{array}{c}0.00 \\
(0.00)\end{array}$ & $\begin{array}{l}33.01 \\
(29.54)\end{array}$ & $\begin{array}{c}0.51 \\
(0.43)\end{array}$ & $\begin{array}{c}92.03 \\
(88.98)\end{array}$ & $\begin{array}{c}3.90 \\
(3.40)\end{array}$ & $\begin{array}{c}43.53 \\
(41.32)\end{array}$ & $\begin{array}{c}20.58 \\
(18.32)\end{array}$ & $\begin{array}{c}0.16 \\
(0.00)\end{array}$ \\
\hline
\end{tabular}

the hypothesis that insurance companies prefer firms with low leverage because they represent less risk.

Corporate governance has a positive and significant coefficient, suggesting that insurance companies tend to invest more in companies with good governance practices. For pension funds, only size and corporate governance have significant coefficients. In both cases, the results indicate that pension funds prefer to invest in large companies with good governance practices.

This result is consistent with the international evidence that institutional investors prefer large firms with liquid shares (Badrinath, Gay and Kale [11]). The positive relation with financial risk is also in line with Cready [7], Badrinath, Gay and Kale [11], and O'Brien and Bhushan [13]. Further, the positive effect on corporate governance is consistent with the results of Badrinath, Kale, and Ryan [12] and Badrinath, Gay and Kale [11].

Although there are significant coefficients for a few variables, it is important to note that the McFadden $\mathrm{R}^{2}$ indicates that the performance of both models is not high and is better for insurance companies when compared to pension funds (0.26 and 0.04).

Table 3 presents the results of the regressions of the determinants of the size of the equity shareholdings of insurance companies and pension funds. Unlike the logit model, the results are not significant. Therefore, the size of the equity shareholding of insurance companies and pension funds can not be explained by the independent variables considered in the study. Except for beta, which is significant at $5 \%$ for insurance companies, and dividend yield, which is significant at $10 \%$ for pension funds, all other variables not statistically significant.

These results are not consistent with the evidence of Table 2 and with the international literature that institutional investors prefer large firms, with liquid shares, high beta, high dividends and good corporate governance. It is important to note that the adjusted $\mathrm{R}^{2}$ indicates that the performance of both models is poor.

Overall, we can conclude that there is a positive relation between liquidity, size, leverage and corporate governance and the probability of a specific firm to be on the equity portfolio of insurance companies and pension funds. However, these variables do not explain the size of the equity shareholding of these investors in a given company.

\section{CONCLUSION}

Insurance companies and pension funds are major investors in the capital market, because they have a large amount of capital available for investment and a great potential for increased investments in stocks. In Brazil, with the current trend of declining interest rates, these institutional investors are increasingly turning to equity in a way to meet the financial obligations of insurance contracts and pension plans. Given that their investments in stocks are still below the limits imposed by Brazilian regulators, especially for insurance companies, understanding their investment strategy becomes important for companies because, with this kind of information, they can target their efforts to attract these investors' capital.

In this study we analyze whether firm characteristics, such as beta, leverage, dividend yield, liquidity, volatility and company size, affect the equity investment decision by insurance companies and pension funds in Brazil. First, we run a logit model to estimate the probability that a company be in the stock portfolio of these institutions. The results of this model indicate that insurance companies tend to invest in large, liquid, leveraged companies with good corporate governance practices, whereas pension funds give preference to big companies with good governance practices. In the second analysis, we run regressions to examine the determinants of the size of equity stake in a given company by in- 
Table 2. Logit Model for Equity Investments by Insurance Companies and Pension Funds in Brazil

Logit Model to Estimate the Probability that a Company be in the Portfolio of Insurance Companies or Pension Funds in December 2006. The Definition of Each Variable can be Found in Section 3. ***, ** e * Denote Statistical Significance at $1 \%, 5 \%$ and $10 \%$, Respectively.

\begin{tabular}{|c|c|c|}
\hline Variable & Insurance Cos. & Pension Funds \\
\hline Beta & $\begin{array}{c}0.09 \\
(0.18)\end{array}$ & $\begin{array}{l}-0.06 \\
(0.40)\end{array}$ \\
\hline Div & $\begin{array}{l}-0.01 \\
(0.12)\end{array}$ & $\begin{array}{c}0.00 \\
(0.83)\end{array}$ \\
\hline Vol & $\begin{array}{c}0.00 \\
(0.20)\end{array}$ & $\begin{array}{c}0.00 \\
(0.78)\end{array}$ \\
\hline F statistic & $\begin{array}{c}3.26^{* * *} \\
(0.00)\end{array}$ & $\begin{array}{c}0.27 \\
(0.96)\end{array}$ \\
\hline McFadden $\mathrm{R}^{2}$ & 0.26 & 0.04 \\
\hline
\end{tabular}

Table 3. Determinants of the Size of Equity Investments by Insurance Companies and Pension Funds in Brazil

Linear regression of the determinants of the size of equity investments of Brazilian insurance companies and pension funds in December 2006. The definition of each variable can be found in Section $3 . * * *$, $* *$ e denote statistical significance at $1 \%, 5 \%$ and $10 \%$, respectively.

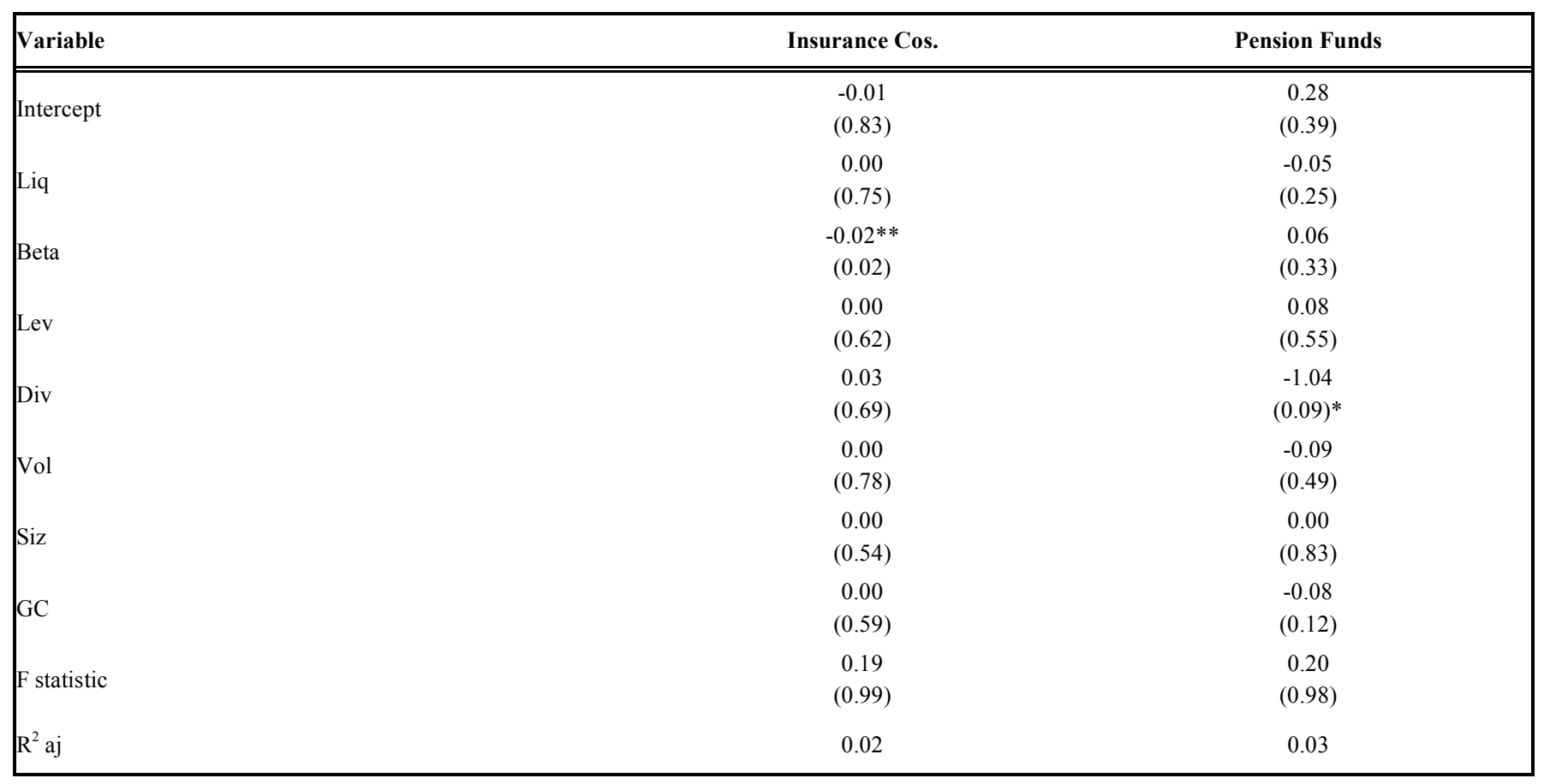

surance companies and pension funds. However, the results of this analysis are not significant.
Overall, we can conclude that, although liquidity, size, leverage and corporate governance does not explain the size of the equity stake held by insurance companies or pension 
funds in a firm, these variables have a good explanatory power to predict whether a company is present in the portfolio of these investors.

\section{REFERENCES}

[1] Badrinath S, Wahala S. Momentum trading by institutions. J Fin 1998; 57: 2449-78.

[2] Jones S, Lee D, Weis E. Herding and feedback trading by different type of institutions and the effects on stock prices. Indiana University Working Paper 1999.

[3] Cummins J, Westerfield R. Patterns of concentration in private pension plan common stock portfolios since ERISA. J Risk Ins 1981; 48: 201-19.

[4] Blake D, Lehmann B, Timmermann, A. Performance clustering and incentives in the UK pension fund industry. J Asset Man 2002; 3: 173-94.

[5] Voronkova S, Bohl M. Institutional traders' behavior in an emerging stock market: empirical evidence on Polish pension fund investors. J Bus Fin Acc 2005; 32: 1537-60.

[6] Hessel C, Norman M. Financial characteristics of neglected and institutional held stocks. J Acc Aud Fin 1992; 7: 313-30.

[7] Cready W. Determinants of relative investor demand for common stocks. J Acc Aud Fin 1994; 10: 487-509.
[8] Eakins S, Stansell S, Wertheim P. Institutional portfolio composition: an examination of the prudent investment hypothesis. Q Rev Econ Fin 1998; 38: 93-109.

[9] Eakins S, Stansell S, Buck J. Analyzing the nature of institutional demand for common stock. Q J Bus Econ 1998; 37: 33-48.

[10] Eakins S, Stansell S, Below S. The determinants of institutional demand for common stock: tests of the CAPM vs. individual stock attributes. Int Rev Fin Anal 1996; 5: 237-57.

[11] Badrinath S, Gay G, Kale J. Patterns of institutional investment, prudence and managerial safety-net hipothesis. J Risk Ins 1989; 56: 605-29.

[12] Badrinath S, Kale J, Ryan H. Characteristics of common stock holdings if insurance companies. J Risk Ins 1996; 63: 49-76.

[13] O'brien P, Bhushan, R. Analyst following and institutional ownership. J Acc Res 1990; 28: 55-76.

[14] Jensen M, Meckling W. Theory of the firm: managerial behaviour, agency costs and ownership structure. J Fin Econ 1976; 3: 305-60.

[15] Black F. The dividend puzzle. J Por Man 1976; 2: 5-8.

[16] Lintner J. Distribution of incomes of corporations among dividends, retained earnings and taxes. Am Econ Rev 1956; 46: 97 113.

[17] Gordon M. Dividends, earning, and stock prices. Rev Econ Stat 1959: 99-105.

[18] Carvalho, A. Efeitos da migração para os níveis de governança da BOVESPA. Terceiro Encontro Brasileiro de Financas 2003: 1: 120.

(C) Andre Carvalhal da Silva; Licensee Bentham Open.

This is an open access article licensed under the terms of the Creative Commons Attribution Non-Commercial License (http://creativecommons.org/licenses/by-nc/3.0/) which permits unrestricted, non-commercial use, distribution and reproduction in any medium, provided the work is properly cited. 